E-JURNAL EKONOMI DAN BISNIS UNIVERSITAS UDAYANA
Available online at https://ojs.unud.ac.id/index.php/EEB/index
Vol. 11 No.01, Januari 2022, pages: 71-86
e-ISSN: 2337-3067

\title{
TRANSFORMASI STRUKTURAL DAN KETIMPANGAN ANTAR KABUPATEN/KOTA DI JAWA BARAT
}

\section{Article history: \\ Submitted: 9 Agustus 2021 \\ Revised: 5 September 2021 \\ Accepted: 17 September 2021}

Bayu Kharisma ${ }^{1}$, Adhitya Wardhana ${ }^{2}$, Yudha Hadian Nur ${ }^{3}$

\section{Abstract}

\section{Keywords:}

Structural Transformation; Inequality;

Location Quotient;

Shift Share;

Williamson Index;

\section{Kata Kunci:}

Transformasi Struktural;

Location Quotient ;

Shift Share;

Williamson Index;

EntropyTheil;

\section{Koresponding:}

Departemen Ilmu Ekonomi

Universitas Padjadjaran

Jawa Barat, Bandung

Email:

bayu.kharisma@unpad.ac.id
This research aims to analyze the structural transformation of the economy and inequality between regions that occur in We st Java. The methods used in this study are Location Quotient (LQ), Shift Share, Williamson Index and Entropy Theil analysis. Meanwhile, the types of data that will be used in this study are secondarydata from 2011 to 2016 . The results of the LQ analysis showed that there are 7 (seven) regions that have an economic base in the industrial sector with Purwakarta as the la rgest contributory region. Meanwhile, 11 (eleven) regions in West Java Province have an economic base in the agricultural sector and the region that contributes the most is Cirebon. Furthermore, there are 8 (eight) re gions that have an economic base in the service sector with Bogor being the region thatcontributes the most. The level of income inequality in West Java Province decreased from 0.670 in 2010 to 0.646 in 2016. It shows the distribution of income that is increasinglyevenly distributed in the period 2010 - 2016 with the average - the largest level of inequality is Purwakarta. Meanwhile, the region with the smallest average level of inequality is Bogor and the smallest level of inequality is Cianjur.

\begin{tabular}{|c|}
\hline Abstrak \\
\hline 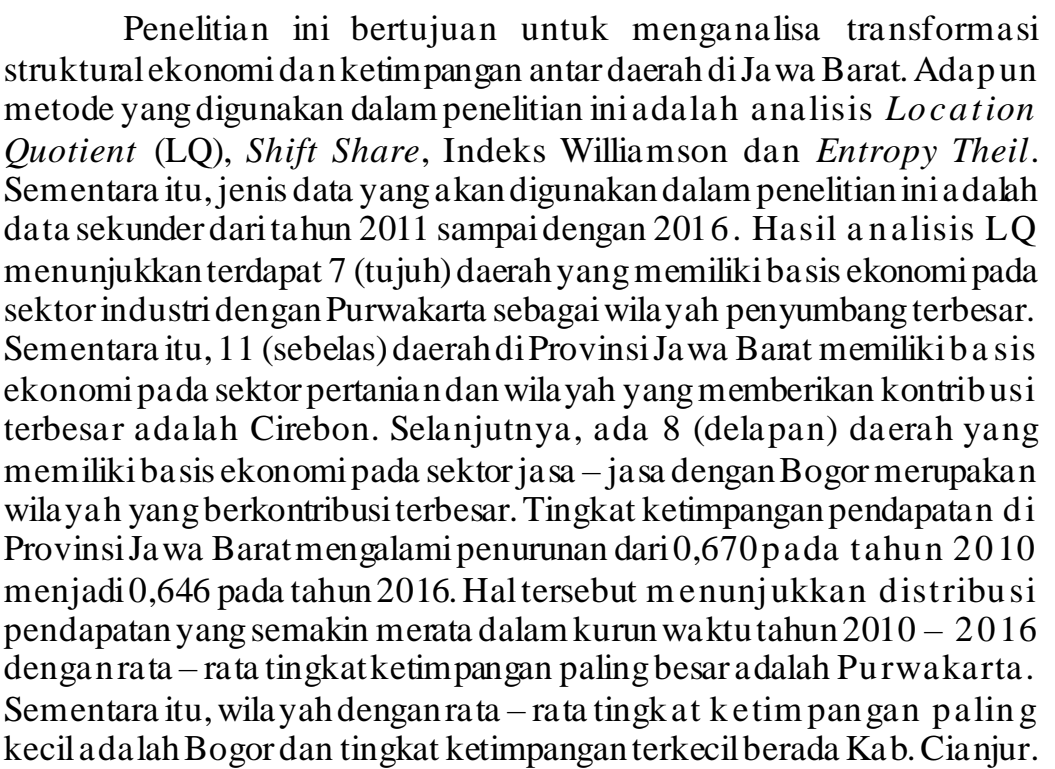 \\
\hline
\end{tabular}

Departemen Ilmu Ekonomi, Universitas Padjadjaran, Jawa Barat, Bandung ${ }^{2}$

Badan Penelitian dan Pengemban gan Daerah Provinsi Ja wa Barat ${ }^{3}$ 


\section{PENDAHULUAN}

Pembangunan ekonomi suatu wilayah tidak lepas dari aspek perubahan atau transformasi struktural ekonomi. Pada dasarnya, terdapat 4 (empat) dimensi pokok dalam pembangungan ekonomi, yakni pertumbuhan, penanggulangan kemiskinan, perubahan atau transformasi ekonomi, dan keberlanjutan pembangunan dari masyarakat agraris menjadi masyarakat industri (Kariyasa, 2006). Terjadinya pembangunan ekonomi di Indonesia telah memacu pertumbuhan ekonomi yang disertai dengan adanya perubahan struktur perekonomian. Chenery \& Srinivasan, (1988) menyatakan bahwa pertumbuhan ekonomi dan perubahan struktur ekonomi memiliki keterkaitan yang cukup erat, bahkan sebagai prasyarat peningkatan dan kesinambungan pertumbuhan ekonomi serta penanggulangan kemiskinan sekaligus sebagai pendukung bagi pembangunan yang berkelanjutan.

Perubahan atau transformasi struktural merupakan proses peralihan struktur perekonomian dari sektor pertanian ke sektor industri atau jasa, dengan bentuk transformasi yang berbeda - beda di setiap perekonomian. Pada umumnya, transformasi struktural yang terjadi di negara berkembang ditandai oleh adanya transformasi dari struktur sektor pertanian yang bersifat tradisional ke industri yang lebih modern. Transformasi ekonomi tersebut berkaitan dengan komposisi permintaan, perdagangan, produksi dan faktor-faktor lain yang diperlukan secara terus menerus untuk meningkatkan perndapatan dan kesejahteraan sosial melalui peningkatan pendapatan perkapita (Amir $\&$ Nazara, 2005). Dengan demikian, proses terjadinya transformasi struktur perekonomian umumnya ditandai oleh beberapa hal seperti, penurunan pangsa sektor primer (pertanian) dan peningkatan pangsa sektor sekunder (industri) terhadap PDB, serta peningkatan kontribusi sektor tersier (jasa) sejalan dengan pertumbuhan ekonomi (Kariyasa, 2006).

Perubahan struktur ekonomi menurut Todaro \& Smith, (2011) tidak hanya memperhatikan perubahan persentase penduduk yang bekerja di berbagai sektor ekonomi tetapi juga memperhatikan perubahan kontribusinya terhadap pembentukan output. Salah satu pola yang jelas dalam perubahan struktural ekonomi adalah seiring dengan terjadinya peningkatan dalam pendapatan per kapita, kontribusi sektor industri terhadap pembentukan produk domestik bruto juga meningkat. Hill, (2000) menyatakan bahwa transformasi struktural ekonomi di Indonesia pada periode tahun 1966 - 1992 berlangsung sangat cepat. Hal tersebut ditandai dengan menurunnya kontribusi dari sektor pertanian terhadap PDB secara signifikan hingga kurang dari setengahnya sejak tahun 1966, dan pada tahun 1992 konstribusi dari sektor pertanian hanya sebesar 36\%. Penurunan ini disertai dengan meningkatnya kontribusi dari sektor industri (mencakup pertambangan, industri manufaktur, fasilitas umum dan konstruksi) sebesar 35\% lebih besar dari nilainya pada pertengahan dekade 1960-an.

Kondisi saat ini di Indonesia, berdasarkan data Badan Pusat Statistik tahun 2017, kontribusi sektor pertanian terhadap pertumbuhan ekonomi Indonesia dalam kurun waktu tujuh tahun terakhir ini juga mengalami penurunan (lihat Gambar 1). Pada tahun 2017, kontribusi sektor pertanian terhadap PDB sebesar $12,68 \%$. Jumlah ini mengalami penurunan jika dibandingkan dengan kontribusi sektor pertanian terhadap PDB pada tahun 2010 yang mencapai 13,93\%. Sektor industri juga mengalami sedikit penurunan, namun jumlah kontribusinya masih lebih besar jika dibandingkan dengan kontribusi sektor pertanian. Pada tahun 2017, kontribusi sektor industri pengolahan terhadap PDB adalah sebesar 21,22\%, sementara pada tahun 2010 kontribusi sektor ini di dalam PDB mencapai 22,04\%. Di sisi lain, kontribusi sektor jasa terhadap PDB pada tahun 2017 adalah sebesar $42,72 \%$ atau meningkat jika dibandingkan dengan kontribusi pada tahun 2010 yang sebesar 40,63\%. Data tersebut menunjukkan bahwa dalam kurun waktu beberapa tahun terakhir ini, Indonesia juga mengalami transformasi struktural ekonomi, dimana kontribusi sektor pertanian terhadap PDB mengalami penurunan dan sebaliknya kontribusi sektor jasa terhadap PDB mengalami kenaikan. 
Hal yang sama terjadi di Jawa Barat, dimana terjadi pergeseran atau transformasi struktural ekonomi dari perekonomian berbasis pertanian ke perekonomian yang berbasis jasa. Hal ini dapat dilihat dari data Badan Pusat Statistik, dimana pada tahun 2017, kontribusi sektor pertanian terhadap PDRB Provinsi Jawa Barat adalah sebesar $7,44 \%$ atau mengalami penurunan jika dibandingkan dengan kontribusi sektor tersebut pada tahun 2010 sebesar $9,83 \%$.

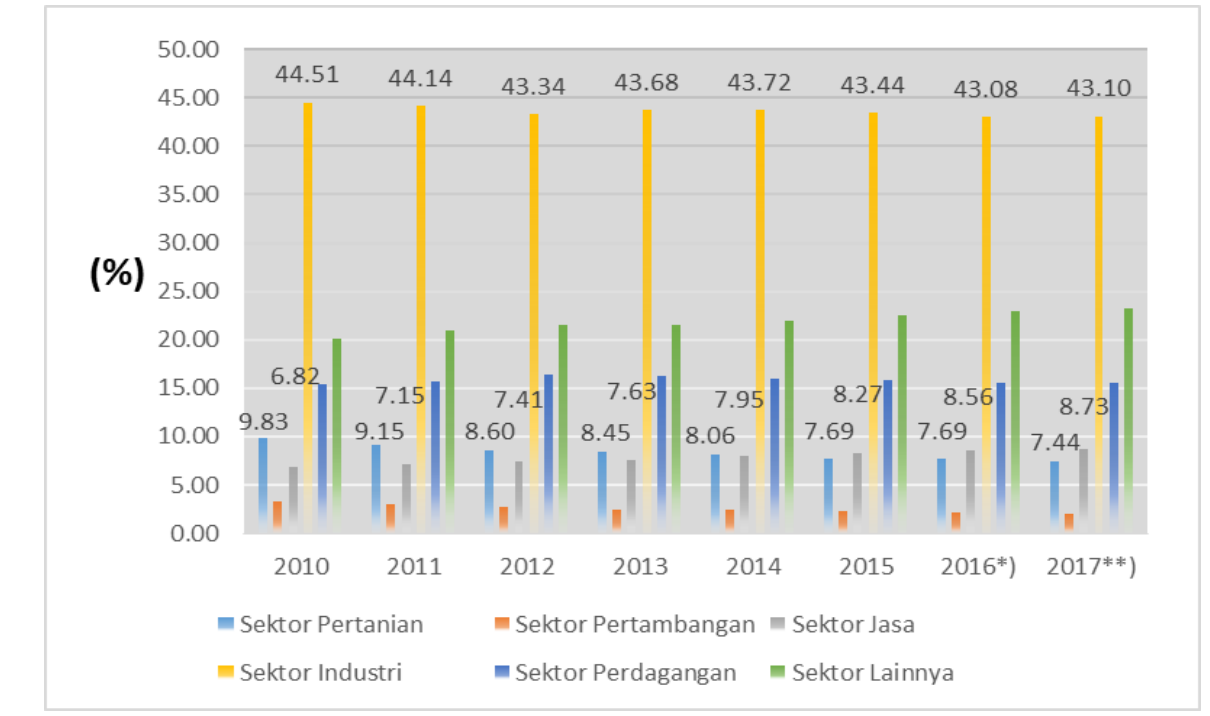

Sumber: BPS, (2019), diolah.

\section{Gambar 1.}

Kontribusi Tiap Sektor Perekonomian Terhadap PDRB Provinsi Jawa Barat 2010 - 2017

Di sisi lain, kontribusi sektor jasa (termasuk di dalamnya jasa keuangan dan asuransi, jasa perusahaan, jasa pendidikan, dan jasa kesehatan dan kegiatan sosial) terhadap PDRB Provinsi Jawa Barat mengalami kenaikan dari 6,82\% pada tahun 2010 menjadi $8,72 \%$ pada tahun 2017 . Sementara itu, sektor industri pengolahan memberikan kontribusi terbesar terhadap PDRB Provinsi Jawa Barat pada kurun waktu tahun 2010 - 2017 dengan rata - rata kontribusinya sebesar 43,63\% per tahun.

Provinsi Jawa Barat memiliki luas wilayah daratan sekitar 3.710.061,32 hektar dengan jumlah penduduk sebanyak 46.709.600 jiwa (Pemprov Jawa Barat, 2020). Secara administratif, Provinsi Jawa Barat terdiri atas 19 Kabupaten dan 9 Kota. Provinsi Jawa Barat merupakan salah satu provinsi dengan tingkat pertumbuhan ekonomi yang tinggi. Pada kurun waktu tahun 2010 - 2017, rata - rata pertumbuhan ekonomi Provinsi Jawa Barat sebesar 5,77\% per tahun. Bahkan pada Triwulan I tahun 2018, perekonomian Jawa Barat tumbuh mencapai 6,02\%, jauh diatas rata-rata pertumbuhan ekonomi nasional pada waktu yang sama yang tumbuh dikisaran 5,06 persen. Berdasarkan laporan BPS Jawa Barat tahun 2018 dari sisi lapangan usaha, sektor yang memberikan andil pertumbuhan terbesar adalah sektor industri pengolahan yaitu 3,19\%. Sementara dari sisi pengeluaran, kontribusi terbesar berasal dari konsumsi rumah tangga sebesar 3,06\%.

Namun demikian, pertumbuhan ekonomi yang relatif tinggi di Provinsi Jawa Barat tidak diikuti dengan pemerataan pendapatan yang diterima oleh setiap lapisan masyarakatnya. Ketimpangan ekonomi di Provinsi Jawa Barat masih cukup tinggi, dimana Gini Ratio Jawa Barat selalu berada di atas rata - rata nasional sejak tahun 2011. Pada September 2016, Provinsi Jawa Barat menempati posisi tertinggi setelah Daerah Istimewa Yogyakarta dan Gorontalo, sebagai provinsi dengan Gini Ratio paling tinggi di Indonesia. Gini Ratio Provinsi Jawa Barat adalah sebesar 0,402, sementara Gini Ratio nasional adalah sebesar 0,394 (Ayu, Riani, \& Haviz, 2019). Hal tersebut menunjukkan bahwa 
transformasi struktural yang diikuti oleh pertumbuhan ekonomi di Provinsi Jawa Barat, tidak disertai dengan semakin kecilnya ketimpangan ekonomi, namun yang terjadi bahwa ketimpangan ekonomi di Provinsi Jawa Barat masih menjadi salah satu yang tertinggi di Indonesia.

Penelitian sebelumnya mengenai tranformasi ekonomi dengan mengetahui sektor unggulan antara lain analisis sektor ekonomi andalan Manado tahun 2001-2010 diketahui dapat meningkatkan struktur perekonomian. Hal tersebut meningkatkan 4 (empat) sektor ekonomi unggulan menjadi 5 (lima) sektor (Hidayat, 2013). Analisis SLQ di Kabupaten Kebumen menunjukkan tidak adanya pergeseran struktur perekonomian. Hasil Klassen Typology menunjukkan bahwa sektor yang maju dan berkembang pesat adalah sektor penggalian dan jasa serta sektor pertambangan. Namun demikian, sektor pertanian dan keuangan, persewaan dan jasa perusahaan diklasifikasikan sebagai sektor maju tetapi tertekan. Manufaktur merupakan sektor yang potensial (Ratnasari, 2017;Basuki \& Gayatri, 2009). Hasil MRP, Shift-Share, LQ, Overlay, dan Tipologi Klassen menunjukkan bahwa potensi ekonomi Kabupaten Ogan Komering Ilir adalah sektor pertanian dan industri pengolahan serta merupakan sektor pertumbuhan yang dominan. Selain itu, sektor tersebut juga menunjukkan perbaikan struktur pertumbuhan ekonomi. Putra \& Yadnya, (2018) menggunakan teknik analisis data Klassen, LQ, dan Overlay Typology di Wilayah Sarbagita untuk mengidentifikasi sektor unggulan. Sektor tersebut adalah grosir dan eceran, jasa keuangan dan asuransi, jasa pendidikan, akomodasi dan makanan dan minuman, informasi dan komunikasi, industri pengolahan, dan administrasi pemerintahan, pertahanan, dan jaminan sosial wajib.

Berdasarkan hal tersebut, maka perlu dilakukan analisis mengenai transformasi struktural ekonomi di Provinsi Jawa Barat dan dampaknya terhadap ketimpangan ekonomi di Provinsi Jawa Barat. Dengan demikian, tujuan yang ingin dicapai dalam penelitian ini adalah bagaimana transformasi struktural ekonomi dan ketimpangan antar daerah yang terjadi di wilayah Jawa Barat. Penelitian sebelumnya fokus pada penentuan sektor-sektor ekonomi basis yang berada di beberapa daerah di Indonesia. Sementara itu, dalam penelitian ini bukan hanya membahas mengenai sektor basis, namun menambahkan informasi mengenai ketimpangan yang terjadi di Jawa Barat.

\section{METODE PENELITIAN}

Metode analisis yang digunakan dalam penelitian ini adalah Location Quotient (LQ), Shift Share, Indeks Williamson dan Entropy Theil. Transformasi Struktural, adapun perubahan struktural dalam kajian ini diukur menggunakan LQ dan Shift Share. Analisis transformasi struktural dilakukan untuk melihat pergeseran peran masing - masing sektor yang ada terhadap PDRB dari masing masing wilayah di Wilayah di Provinsi Jawa Barat yang dibagi atas 4 (empat) kluster berdasarkan Badan Koordinasi Pemerintahan dan Pembangunan Wilayah yaitu : Wilayah I: Kabupaten dan Kota Bogor. Wilay ah II: Kabupaten Purwakarta, Kabupaten Karawang, Kabupaten dan Kota Bekasi dan Ka bupaten Subang. Wila yah III: Kota dan Kabupaten Cirebon, Ka bupaten Ind ramayu, Ka bupaten Majalen gka dan Kabupaten Kuningan. Wilayah IV: Kabupaten dan Kota Bandung, Kabupaten Bandung Ba rat, Kabupaten Garut, Kabupaten Sumedang, Kabupaten dan Kota Tasikmalaya, Ka bupaten Ciamis, Kota Cimahi, Kota Banjar.

Ketimpangan a ntar daerah di Wilay ah I sampaiIV di Jawa Barat dianalisis dengan m empergu nakan indeks ketimpangan regional (Regional Inequality Index) yaitu: Index Willia mson, Index Entropy Theil. Jenis data yang akan digunakan dalam penelitian ini adalah data sekunder dan primer. Data sekunder yang digunakan dalam kajian ini dari tahun 2011 sampai dengan 2016. Adapun dalam kajian ini data sekunder yang dipakai adalah data berkala (time series) yang berasal dari data publikasi Badan Pusat Statistik, yaitu Data PDRB masing - masing Kabupaten - Kota di Wilayah Pembangunan I sampai IV di Jawa Barat atas dasar harga konstan yang didapat dari Badan Pusat Statistik Propinsi Jawa Barat. 
Selain itu, data jumlah penduduk masing-masing Kabupaten/Kota di Wilayah Pembangunan I sampai IV di Jawa Barat.

\section{HASIL DAN PEMBAHASAN}

Secara umum, nilai LQ > 1 menunjukkan bahwa subsektor tersebut merupakan subsektor unggulan di daerah dan potensial untuk dikembangkan sebagai penggerak perekonomian daerah. Namun, apabila LQ < 1 maka subsektor tersebut bukan merupakan subsektor unggulan dan kurang potensial untuk dikembangkan sebagai penggerak perekonomian daerah.

Sebagai informasi bahwa Provinsi Jawa Barat terbagi dalam 4 Badan Koordinasi Pemerintahan Pembangunan (Bakor PP) Wilayah, diantaranya adalah: Wilayah I Bogor yang meliputi Kabupaten Bogor, Kota Bogor, Kota Depok, Kabupaten Sukabumi, Kota Sukabumi, dan Kabupaten Cianjur; Wilayah II Purwakarta meliputi Kabupaten Purwakarta, Kabupaten Subang, Kabupaten Karawang, Kabupaten Bekasi, dan Kota Bekasi; Wilayah III Cirebon meliputi Kabupaten Cirebon, Kota Cirebon, Kabupaten Indramayu, Kabupaten Majalengka, dan Kabupaten Kuningan; dan Wilayah IV Priangan meliputi Kabupaten Bandung, Kota Bandung, Kota Cimahi, Kabupaten Bandung Barat, Kabupaten Sumedang, Kabupaten Garut, Kabupaten Tasikmalaya, Kota Tasikmalaya, Kabupaten Ciamis, dan Kota Banjar.

Tabel 1.

Analisis LQ di Kabupaten/Kota di Wilayah I Jawa Barat Tahun 2011 - 2015

\begin{tabular}{|c|c|c|c|c|c|c|}
\hline Sektor & Kab.Bogor & Kota. Bogor & Kota Depok & $\begin{array}{l}\text { Kab. } \\
\text { Sukabumi }\end{array}$ & $\begin{array}{l}\text { Kota } \\
\text { Sukabumi }\end{array}$ & $\begin{array}{l}\text { Kab. } \\
\text { Cianjur }\end{array}$ \\
\hline 1 & 0,65 & 0,11 & 0,17 & 2,67 & 0,48 & 4,07 \\
\hline 2 & 1,26 & & & 3,48 & & 0,13 \\
\hline 3 & 1,28 & 0,44 & 0,78 & 0,35 & 0,13 & 0,13 \\
\hline 4 & 0,35 & 7,59 & 0,54 & 0,20 & 0,36 & 0,17 \\
\hline 5 & 1,44 & 1,37 & 1,00 & 0,34 & 1,68 & 0,41 \\
\hline 6 & 1,07 & 1,40 & 2,37 & 1,38 & 0,79 & 1,06 \\
\hline 7 & 0,80 & 1,41 & 1,30 & 1,26 & 2,65 & 1,15 \\
\hline 8 & 0,65 & 2,48 & 0,79 & 1,39 & 2,01 & 1,82 \\
\hline 9 & 0,99 & 1,83 & 1,28 & 1,01 & 1,07 & 2,38 \\
\hline 10 & 0,65 & 1,70 & 0,67 & 0,84 & 1,31 & 1,07 \\
\hline 11 & 0,21 & 2,78 & 1,58 & 0,29 & 3,97 & 0,93 \\
\hline 12 & 0,72 & 1,91 & 1,45 & 1,42 & 1,02 & 1,83 \\
\hline 13 & 0,49 & 5,07 & 0,59 & 0,77 & 3,83 & 1,67 \\
\hline 14 & 0,80 & 1,27 & 1,24 & 1,42 & 2,49 & 1,31 \\
\hline 15 & 0,70 & 1,07 & 1,03 & 1,56 & 1,33 & 1,67 \\
\hline 16 & 0,70 & 1,72 & 1,50 & 1,23 & 2,39 & 1,07 \\
\hline 17 & 0,88 & 1,72 & 1,93 & 0,85 & 1,54 & 1,93 \\
\hline $\begin{array}{l}\text { Sumber } \\
\text { Keterang } \\
\text { Sektor 1: } \\
\text { Sektor 2: }\end{array}$ & $\begin{array}{l}\text { adan Pusat Sta } \\
\text { rtanian, Kehutar } \\
\text { rtambangan dan }\end{array}$ & $\begin{array}{l}2016 \text { (diolah) } \\
\text { n Perikanan } \\
\text { alian }\end{array}$ & & & & \\
\hline
\end{tabular}

Transformasi Struktural Dan Ketimpangan Antar Kabupaten/Kota Di Jawa Barat, Bayu Kharisma, Adhitya Wardhana dan Yudha Hardian Nur 
Sektor 3: Industri Pengolahan

Sektor 4: Pengadaan Listrik dan Air

Sektor 5: Pengadaan Air, Pengelolaan Sampah, Limbah dan Daur Ulang

Sektor 6: Konstruksi

Sektor 7: Perdagangan Besar dan Eceran; Reparasi Mobil dan Sepeda Motor

Sektor 8: Transportasi dan Pergudangan

Sektor 9: Penyediaan Akomodasi dan Makan Minum

Sektor 10: Informasi dan Komunikasi

Sektor 11: Jasa Keuangan dan Asuransi

Sektor 12: Real Estat

Sektor 13: Jasa Perusahaan

Sektor 14: Administrasi Pemerintahan, Pertahanan dan Jaminan Sosial Wajib

Sektor 15: Jasa Pendidikan

Sektor 16: Jasa Kesehatan dan Kegiatan Sosial

Sektor 17: Jasa Lainnya

Pada kawasan Wilayah I Bogor, Provinsi Jawa Barat, terdapat beberapa daerah yang memiliki keunggulan di subsektor pertanian, yakni di Kabupaten Cianjur dan Sukabumi. Di wilayah tersebut, subsektor pertanian memiliki tingkat spesialisasi yang lebih besar dibandingkan dengan sektor yang sama di tingkat provinsi. Hal tersebut tidak mengherankan mengingat bahwa kedua kabupaten tersebut merupakan daerah sentra utama penghasil beras di Jawa Barat dan bahkan di Indonesia. Hasil analisis LQ untuk wilayah pembangunan I pada periode tahun 2011 - 2015 dapat dilihat pada Tabel 1.

Sementara itu, untuk subsektor industri pengolahan, hanya di wilayah Kabupaten Bogor yang memiliki keunggulan pada subsektor tersebut. Di beberapa wilayah lainnya, subsektor industri pengolahan bukan merupakan sektor unggulan dan bahkan memiliki spesialisasi yang lebih rendah dibandingkan dengan sektor yang sama di tingkat provinsi. Untuk subsekktor jasa - jasa, secara umum hampir di seluruh kabupaten/kota di wilayah I, subsektor jasa sudah cukup berkembang dan bahkan memiliki spesialisasi yang lebih tinggi dibandingkan dengan sektor yang sama di tingkat provinsi. Namun, di Kabupaten Bogor, subsektor jasa masih belum berkembang dan belum menjadi subsektor unggulan di wilayah ini.

Secara umum, perekonomian di wilayah I Jawa Barat sudah cukup berkembang ditandai dengan banyaknya subsektor yang menjadi basis perekonomian di wilayah ini. Namun demikian, berdasarkan analisis LQ, Kabupaten Bogor merupakan wilayah yang paling sedikit memiliki subsektor unggulan. Di wilayah ini, hanya terdapat 3 subsektor yang memiliki spesialisasi yang lebih tinggi dibandingkan dengan subsektor yang sama di tingkat provinsi yakni subsektor Pertambangan dan Penggalian; Industri Pengolahan; dan Pengadaan Air, Pengelolaan Sampah, Limbah dan Daur Ulang. Sebaliknya, Kota Bogor merupakan wilayah yang memiliki paling banyak subsektor unggulan. Hampir seluruh subsektor yang terdapat pada struktur ekonomi Kota Bogor merupakan subsektor unggulan, hanya terdapat 2 subsektor yang bukan merupakan unggulan yakni subsektor Pertanian, Kehutanan dan Perikanan, dan subsektor industri pengolahan.

Hasil analisis LQ pada wilayah II Purwakarta menunjukkan bahwa masih banyak sektor yang belum dikembangkan optimal di beberapa kabupaten/kota di wilayah ini. Hal tersebut ditunjukkan dengan masih banyaknya sektor yang memiliki nilai LQ $<1$, dengan kata lain memiliki tingkat spesialisasi yang lebih rendah dibandingkan dengan sektor yang sama di tingkat provinsi.

Di Kabupaten Purwakarta, hanya terdapat beberapa sektor yang memiliki tingkat spesialisasi yang lebih besar dibandingkan dengan sektor yang sama di tingkat provinsi yakni industri pengolahan; pengadaan listrik dan gas; real estat; jasa perusahaan; dan jasa lainnya. Dengan kata lain, sektor sektor tersebut merupakan subsektor unggulan yang potensial untuk dikembangkan sebagai basis perekonomian daerah. 
Di Kabupaten Subang, terdapat beberapa sektor yang merupakan subsektor unggulan dan potensial untuk dikembangkan yakni sektor pertanian, kehutanan, dan perikanan; pertambangan dan penggalian; pengadaan air, pengelolaan sampah, limbah dan daur ulang; penyediaan akomodasi dan makan minum; jasa keuangan dan asuransi; administrasi pemerintahan, pertahanan dan jaminan sosial; jasa pendidikan; jasa kesehatan dan kegiatan sosial; dan jasa lainnya. Subsektor yang memiliki tingkat spesialisasi yang cukup tinggi dibandingkan dengan sektor yang sama di tingkat provinsi adalah sektor pertanian, kehutanan dan perikanan; dan sektor pertambangan dan penggalian. Sementara itu, di Kabupaten Karawang, hanya terdapat sedikit sektor yang menjadi basis perekonomian di daerah ini yakni sektor pertambangan dan penggalian; industri pengolahan; dan pengadaan listrik dan gas. Ketiga sektor tersebut yang menjadi sektor unggulan di Kabupaten Karawang dan potensial untuk dikembangkan.

Tabel 2.

Analisis LQ di Kabupaten/Kota di Wilayah II Jawa Barat Tahun 2011-2015

\begin{tabular}{lllll}
\hline Sektor & Kab.Purwakarta & Kab.Subang & Kab. Karawang & Kab. Bekasi \\
\hline 1 & 0,84 & 3,34 & 0,46 & 0,16 \\
2 & 0,04 & 5,02 & 1,19 & 0,61 \\
3 & 1,36 & 0,26 & 1,64 & 1,18 \\
4 & 1,20 & 0,13 & 1,56 & 1,53 \\
5 & 0,36 & 1,16 & 0,78 & 0,30 \\
6 & 0,86 & 0,96 & 0,45 & 0,75 \\
7 & 0,78 & 0,97 & 0,64 & 0,37 \\
8 & 0,47 & 0,81 & 0,37 & 0,21 \\
9 & 0,45 & 1,47 & 0,38 & 0,19 \\
10 & 0,50 & 0,95 & 0,30 & 0,29 \\
11 & 0,87 & 1,73 & 0,44 & 0,33 \\
12 & 1,11 & 0,88 & 0,20 & 0,34 \\
13 & 1,00 & 0,11 & 0,08 & 0,28 \\
14 & 0,61 & 1,83 & 0,43 & 0,33 \\
15 & 0,75 & 1,22 & 0,28 & 0,29 \\
16 & 0,59 & 1,01 & 0,38 & 0,28 \\
17 & 1,01 & 1,19 & 0,40 & 0,27 \\
\hline
\end{tabular}

Sumber: Badan Pusat Statistik, 2016(diolah)

Secara umum, di wilayah III Cirebon, hampir di seluruh kabupaten/kota yang berada di wilayah ini sudah memiliki perekonomian yang cukup baik. Hal tersebut dapat dilihat dari nilai LQ yang menunjukkan bahwa hampir seluruh sektor yang berada di kabupaten/kota di wilayah ini memiliki spesialisasi yang lebih besar dibandingkan dengan sektor yang sama di tingkat provinsi. Diantara seluruh Kabupaten/Kota di wilayah ini, hanya di Kabupaten Indramayu yang memiliki paling sedikit sektor unggulan. Di Kabupaten Indramayu, hanya terdapat 3 sektor unggulan yakni sektor pertanian, kehutanan dan perikanan; pertambangan dan penggalian; dan indsutri pengolahan. 
Sementara itu, sektor - sektor lainnya di Kabupaten Karawang memiliki tingkat spesialisasi yang lebih kecil dibandingkan dengan sektor yang sama di tingkat provinsi.

Di Kabupaten Cirebon, hampir seluruh sektor merupakan sektor unggulan dengan tingkat spesialisasi yang lebih besar dibandingkan dengan sektor yang sama di tingkat provinsi. Hanya terdapat beberapa sektor yang memiliki tingkat spesialisasi yang lebih rendah, yakni sektor industri pengolahan; pengadaan listrik dan gas; dan informasi dan komunikasi. Sebaliknya, beberapa sektor dengan tingkat spesialisasi yang paling tinggi di Kabupaten Cirebon antara lain adalah sektor pertanian, kehutanan dan perikanan; jasa kesehatan dan kegiatan sosial; dan jasa perusahaan. Ketiga sektor tersebut merupakan sektor unggulan di Kabupaten Cirebon dan potensial untuk dikembangkan.

Di Kota Cirebon, hampir seluruh sektor merupakan sektor unggulan dengan tingkat spesialisasi yang lebih besar dibandingkan dengan sektor yang sama di tingkat provinsi. Hanya terdapat beberapa sektor yang memiliki tingkat spesialisasi yang lebih kecil yakni sektor pertanian, kehutanan dan perikanan; industri pengolahan; dan real estat. Sementara itu, sektor dengan tingkat spesialisasi tertinggi di Kota Cirebon antara lain adalah sektor jasa keuangan dan asuransi; pengadaan air, pengelolaan sampah, limbah dan daur ulang; dan sektor jasa kesehatan dan kegiatan sosial. Ketiga sektor tersebut merupakan sektor unggulan dan potensial untuk dikembangkan sebagai basis ekonomi di Kota Cirebon.

Tabel 3.

Analisis LQ di Kabupaten/Kota di Wilayah III Jawa Barat Tahun 2011 - 2015

\begin{tabular}{|c|c|c|c|c|c|c|}
\hline & Sektor & Kab. Cirebon & Kab. Cirebon & $\begin{array}{l}\text { Kab. } \\
\text { Indramayu }\end{array}$ & $\begin{array}{l}\text { Kab. } \\
\text { Majalengka }\end{array}$ & Kab. Kuningan \\
\hline$\overline{1}$ & & 2,00 & 0,04 & 1,81 & 3,09 & 2,87 \\
\hline 2 & & & & 6,68 & 1,16 & 0,76 \\
\hline 3 & & 0,47 & 0,24 & 1,05 & 0,31 & 0,06 \\
\hline 4 & & 0,31 & 2,05 & 0,08 & 0,16 & 0,19 \\
\hline 5 & & 1,04 & 3,57 & 0,88 & 0,72 & 1,16 \\
\hline 6 & & 1,48 & 1,30 & 0,54 & 1,49 & 1,09 \\
\hline 7 & & 1,02 & 2,07 & 0,60 & 1,12 & 1,10 \\
\hline 8 & & 1,56 & 2,30 & 0,46 & 0,84 & 3,02 \\
\hline 9 & & 1,50 & 1,99 & 0,53 & 1,37 & 0,72 \\
\hline 10 & & 0,84 & 1,69 & 0,18 & 1,12 & 1,39 \\
\hline 11 & & 1,39 & 4,37 & 0,40 & 1,21 & 2,13 \\
\hline 12 & & 1,97 & 0,82 & 0,35 & 1,17 & 2,68 \\
\hline 13 & & 2,01 & 2,12 & 0,49 & 0,89 & 1,04 \\
\hline 14 & & 1,46 & 1,79 & 0,91 & 1,78 & 1,88 \\
\hline 15 & & 1,87 & 1,27 & 0,64 & 2,21 & 3,36 \\
\hline 16 & & 2,82 & 3,02 & 0,52 & 1,45 & 2,23 \\
\hline 17 & & 1,84 & 1,12 & 0,18 & 1,43 & 1,74 \\
\hline
\end{tabular}

Sumber: Badan Pusat Statistik, 2016 (diolah)

Sama halnya dengan Kabupaten dan Kota Cirebon, di Kabupaten Majalengka dan Kabupaten Kuningan, hampir seluruh sektor merupakan sektor unggulan dengan tingkat spesialisasi yang lebih 
tinggi dibandingkan dengan sektor yang sama di tingkat provinsi. Di Kabupaten Majalengka beberapa sektor dengan tingkat spesialisasi tertinggi adalah sektor pertanian, kehutanan dan perikanan dan $\mathrm{j}$ asa pendidikan. Kedua sektor tersebut merupakan sektor yang paling unggul di Kabupaten Majalengka dan potensial untuk dikembangkan. Sementara itu, sektor paling unggul di Kabupaten Kuningan antara lain adalah sektor transportasi dan pergudangan; pertanian, kehutanan dan perikanan; real estat; dan jasa keuangan dan asuransi.

Wila yah IV Priangan merupakan wilayah pembangunan dengan jumlah kabupaten/kota paling ba nyak di Provinsi Ja wa Barat. Gambaran perekonomian di wilay ah ini sangat bervariasi men gin gat di wila y ah ini terda pat sebanyak 10 kabupaten/kota. Na mun, secara umum setiap kabupaten dan kota y ang terdapat di wila y ah ini memiliki spesialisasi di sektor yang berbeda - beda satu dengan y ang la in nya. Untuk sektor pertanian, kehutanan dan perikanan, terdapat beberapa wila yah y ang memiliki keunggulan pada sektor ini yakni Kabupaten Ta sikmalaya, Kabupaten Ga rut, Ka bupaten Ciamis, Kabupaten Sumedang, Kabupaten Bandung Barat, dan Kot a Banjar. Sementara itu, wilay ah yang memiliki keunggulan pada sektor industri pengolahan hanya terdapat di dua wila y ah yakni Kabupaten Bandung dan Kota Cimahi. Di sisi lain, sektor jasa su dah sangat berkembang dan menjadi sektor unggulan di hampir seluruh kabupaten/kota di wila yah ini. Salah sa tu yang paling unggul a dalah sektor Informasi dan Komunikasi di Kota Bandung yang memilikitingkat spesialisa si y ang ja uh leb ih be sar dibandingkan dengan sektor y ang sa ma di tingkat provinsi.

Analisis ini digunakan untuk mengetahui perubahan struktur/kinerja ekonomi daerah terhadap struktur ekonomi yang lebih tinggi (provinsi atau nasional) sebagai referensi. Perubahan relatif kinerja pembangunan daerah terhadap nasional dapat dilihat dari: National growth effect: pengaruh pertumbuhan ekonomi na sional terhadap daerah, atau disebut juga national share. Proportional shift: menguk ur perubahan rela tif (naik/turun) suatu sektor daerah terhadap sektor yang sa ma di tingk at n asional, disebut ju ga bauran industri (industry mix). Differential shift: mengetahui seberapa kompetitif sektor tertentu daerah dibanding nasional. Jika nilainya (+) berarti kompetitif, jika nilainya (-) tidak kompetitif. Disebut juga pengaruh keunggulan kompetitif.

Analisis shift share pada wilayah I Bogor dapat dilihat dari hasil perhitungan untuk bauran industri (industry mix), yang merupakan komponen pembentuk PDRB. Bauran industri yang bernilai positif menunjukkan bahwa rata - rata laju pertumbuhan sektor di daerah memiliki pertumbuhan lebih cepat dibandingkan dengan pertumbuhan sektor yang sama di tingkat provinsi. Analisis bauran industri pada wilayah I Bogor berdasarkan perhitungan PDRB dari tahun 2012 hingga 2016.

Analisis shift share menunjukkan bahwa di seluruh kabupaten/kota yang terdapat pada wilayah I Bogor memiliki pola yang sama pada perekonomiannya, dimana terdapat beberapa sektor yang memiliki nilai positif antara lain: sektor pengadaan air, pengelolaan sampah, limbah dan daur ulang; konstruksi; transportasi dan pergudangan; penyediaan akomodasi dan makan minum; informasi dan komunikasi; jasa keuangan dan asuransi; jasa perusahaan; jasa pendidikan; jasa kesehatan dan kegiatan sosial; jasa lainnya. Hasil tersebut menunjukkan bahwa pertumbuhan ekonomi di wilayah I Bogor terkonsentrasi pada sektor - sektor tersebut, dimana pertumbuhan sektoral di daerah lebih cepat dibandingkan dengan pertumbuhan sektor yang sama di tingkat provinsi. Lebih lanjut, hasil tersebut juga menunjukkan bahwa di wilayah I Bogor, perekonomian sudah tidak terkonsentrasi pada sektor sektor primer seperti pertanian, kehutanan, perikanan, dan juga sektor industri pengolahan. Perekonomian di wilayah ini lebih terkonsentrasi pada sektor - sektor jasa, dimana sektor ini mampu memberikan sumbangan pada perekonomian wilayah, dengan pertumbuhan yang lebih tinggi dibandingkan dengan sektor yang sama di tingkat provinsi.

Keunggulan kompetitif ditunjukkan dari hasil perhitungan differential shift atau regional shift. Notasi positif menunjukkan bahwa sektor tersebut memiliki daya saing atau keunggulan dibandingkan dengan sektor yang sama di tingkat provinsi, dan sebaliknya. Tabel 6 menunjukkan bahwa di wilayah 
ini terdapat beberapa kabupaten/kota yang memiliki keunggulan di sektor yang berbeda - beda sesuai dengan kekhususan wilayahnya.

Di Kabupaten Bogor, hampir semua sektor merupakan sektor unggulan atau memiliki daya saing yang lebih tinggi dibandingkan dengan sektor yang sama di tingkat provinsi. Kabupaten Bog or memiliki keunggulan baik di sektor pertanian, kehutanan dan perikanan, maupun sektor jasa - jasa. Namun, sektor industri pengolahan di Kabupaten Bogor bukan merupakan sektor unggulan atau memiliki daya saing yang lebih rendah dibandingkan dengan sektor yang sama di tingkat provinsi. Hal tersebut bertolak belakang dengan hasil analisis LQ yang menunjukkan bahwa sektor industri pengolahan di Kabupaten Bogor memiliki spesialisasi yang lebih tinggi. Disamping itu, sektor industri juga menjadi penyumbang terbesar dalam PDRB Kabupaten Bogor. Hasil ini menunjukkan bahwa Pemerintah Kabupaten Bogor dapat lebih mengoptimalkan pendapatan dari sektor - sektor lain (selain industri pengolahan), yang memiliki daya saing yang lebih tinggi.

Di Kota Bogor, beberapa sektor yang merupakan sektor unggulan antara lain adalah industri pengolahan; pengadaan air, pengelolaan sampah, limbah dan daur ulang; perdagangan besar dan eceran, reparasi mobil dan sepeda motor; informasi dan komunikasi; real estat; dan administrasi pemerintahan, pertahanan dan jaminan sosial wajib. Hasil tersebut sesuai dengan struktur PDRB Kota Bogor yang menunjukkan bahwa sektor - sektor tersebut memberikan sumbangan yang cukup besar pada PDRB Kota Bogor, terutama untuk sektor perdagangan besar dan eceran; reparasi mobil dan sepeda motor yang memberikan sumbangan terbesar pada PDRB Kota Bogor. Di Kota Depok terdapat beberapa sektor yang merupakan sektor unggulan yakni sektor pengadaan listrik dan gas; konstruksi; pedagangan besar dan eceran, reparasi mobil dan sepeda motor; penyediaan akomodasi dan makan minum; jasa keuangan dan asuransi; real estat; jasa pendidikan; dan jasa lainnya. Hasil tersebut menunjukkan bahwa perekonomian di Kota Depok memiliki keunggulan pada sektor jasa dan perdagangan. Hal tersebut bertolak belakang dengan struktur PDRB Kota Depok dimana penyumbang terbesar adalah sektor industri pengolahan, sementara hasil analisis tersebut menunjukkan bahwa sektor industri pengolahan di kota Depok tidak memiliki keunggulan kompetitif. Oleh karena itu, pemerintah Kota Depok dapat lebih mengembangkan sektor jasa yang lebih memiliki keunggulan kompetitif.

Kabupaten Sukabumi memiliki keunggulan di sektor pertanian, kehutanan dan perikanan; pertambangan dan penggalian; industri pengolahan; pengadaan listrik dan gas; konstruksi; perdagangan besar dan eceran, reparasi mobil dan sepeda motor; dan real estat. Sementara itu, sektor jasa - jasa bukan merupakan sektor unggulan di Kabupten Sukabumi. Di Kota Sukabumi hanya terdapat beberapa sektor unggulan antara lain sektor pengadaan listrik dan gas; kostruksi; perdagangan besar dan eceran, reparasi mobil dan sepeda motor; dan penyediaan akomodasi dan makan minum. Sementara itu, sektor - sektor lainnya seperti pertanian, industri dan jasa, bukan merupakan sektor unggulan. Hal tersebut menjadi tugas bagi pemerintah Kota Sukabumi untuk dapat meningkatkan daya saing sektor - sektor lainnya untuk menjadi penggerak perekonomian Kota Sukabumi. Kabupaten Cianjur memiliki keunggulan di sektor Pertanian, Kehutanan dan Perikanan. Hal tersebut tidak mengherankan mengingat Kabupaten Cianjur merupakan salah satu daerah utama penghasil beras di Indonesia. Selain itu, sektor pertanian, kehutanan dan perikanan juga memberikan sumbangan terbesar pada PDRB Kabupaten Cianjur. Di samping itu, Kabupaten Cianjur juga memiliki keunggulan di sektor lainnya seperti pertambangan dan penggalian; pengadaan listrik dan gas; perdagangan besar dan eceran, reparasi mobil dan sepeda motor; penyediaan akomodasi dan makan minum; real estat; administrasi pemerintahan, pertahanan dan jaminan sosial; dan jasa kesehatan dan kegiatan sosial.

Hasil analisis untuk bauran industri di wilayah II Purwakarta menunjukkan pola yang sama dengan wilayah I bogor dimana terdapat beberapa sektor yang memiliki nilai positif antara lain: sektor 
pengadaan air, pengelolaan sampah, limbah dan daur ulang; konstruksi; transportasi dan pergudangan; penyediaan akomodasi dan makan minum; informasi dan komunikasi; jasa keuangan dan asuransi; jasa perusahaan; jasa pendidikan; jasa kesehatan dan kegiatan sosial; jasa lainnya. Hasil ini menunjukkan bahwa pertumbuhan ekonomi di wilayah II Purwakarta terkonsentrasi pada sektor sektor tersebut, dimana pertumbuhan sektoral di daerah lebih cepat dibandingkan dengan pertumbuhan sektor yang sama di tingkat provinsi.

Hasil analisis keunggulan kompetitif di wilayah II Purwakarta menujukkan hasil yang berbeda antar kabupaten/kota yang terdapat di wilayah ini. Di Kabupaten Purwakarta, beberapa sektor yang menjadi unggulan atau memiliki daya saing yang lebih tinggi dibandingkan dengan sektor yang sama di tingkat provinsi antara lain adalah sektor pertanian, kehutanan dan perikanan; pertambangan dan penggalian; industri pengolahan; pengadaan listrik dan gas; perdagangan besar dan eceran, reparasi mobil dan sepeda motor; dan sektor jasa - jasa. Hasil tersebut sesuai dengan struktur PDRB Kabupaten Purwakarta yang menujukkan bahwa sektor industri pengolahan memberikan kontribusi terbesar pada PDRB Kabupaten Purwakarta. Namun, sektor jasa - jasa belum memberikan kontribusi yang cukup besar meskipun sektor tersebut merupakan sektor unggulan di daerah ini. Oleh karena itu, pemerintah Kabupaten Purwakarta perlu untuk mengoptimalkan sektor jasa - jasa yang terdapat di daerah ini.

Kabupaten Subang, masih sedikit sektor yang menjadi unggulan, antara lain adalah sektor pertambangan dan penggalian; pengadaan listrik dan gas; konstruksi; perdagangan besar dan eceran, reparasi mobil dan sepeda motor; administrasi pemerintahan, pertahanan dan jaminan sosial wajib; dan jasa pendidikan. Hal tersebut bertolak belakang dengan struktur PDRB Kabupaten Subang, dimana sektor pertanian, kehutanan dan perikanan memberikan kontribusi terbesar dalam PDRB Kabupaten Subang. Sementara, hasil analisis ini menunjukkan bahwa sektor pertanian, kehutanan dan perikanan bukan merupakan sektor unggulan di Kabupaten Subang. Dengan demikian, Pemerintah Kabupaten Subang perlu meningkatkan sektor - sektor lain (selain pertanian) yang lebih memiliki keunggulan atau daya saing. Di Kabupaten Karawang, hampir seluruh sektor memiliki daya saing yang lebih tinggi dibandingkan dengan sektor yang sama di tingkat provinsi. Salah satu sektor yang memiliki keunggulan kompetitif adalah sektor industri pengolahan. Sektor ini juga memberikan kontribusi terbesar pada PDRB Kabupaten Karawang. Namun demikian, sektor pertanian, kehutanan dan perikanan, meskipun memberikan kontribusi yang cukup besar bagi PDRB Kabupaten Karawang, namun sektor tersebut bukan merupakan sektor yang memiliki keunggulan kompetitif di Kabupaten Karawang.

Kabupaten Bekasi memiliki keunggulan pada sektor jasa - jasa. Sementara itu, sektor pertanian dan industri pengolahan di Kabupaten Bekasi tidak memiliki keunggulan kompetitif. Hal tersebut juga bertolak belakang dengan struktur PDRB Kabupaten Bekasi dimana sektor industri pengolahan memberikan kontribusi terbesar pada PDRB Kabupaten Bekasi. Bahkan, lebih dari 50\% dari pendapatan Kabupaten Bekasi berasal dari sektor industri pengolahan. Hal tersebut dapat menjadi tugas bagi Pemerintah Kabupaten Bekasi untuk meningkatkan daya saing sektor industri pengolahan di Kabupaten Bekasi, agar sektor ini bisa menjadi basis perekonomian yang berkelanjutan.

Hasil analisis untuk bauran industri di wilayah II Cirebon menunjukkan pola yang sama dengan wilayah lainnya dimana terdapat beberapa sektor yang memiliki nilai positif antara lain: sektor pengadaan air, pengelolaan sampah, limbah dan daur ulang; konstruksi; transportasi dan pergudangan; penyediaan akomodasi dan makan minum; informasi dan komunikasi; jasa keuangan dan asuransi; jasa perusahaan; jasa pendidikan; jasa kesehatan dan kegiatan sosial; jasa lainnya. Hasil tersebut menunjukkan bahwa pertumbuhan ekonomi di wilayah III Cirebon terkonsentrasi pada sektor - sektor 
tersebut, dimana pertumbuhan sektoral di wilayah ini lebih cepat dibandingkan dengan pertumbuhan sektor yang sama di tingkat provinsi.

Hasil analisis keunggulan kompetitif sektoral di wilayah ini juga bervariasi di tiap kabupaten/kota yang berada di wilayah III Cirebon (lihat Tabel 10). Secara umum, Kabupaten Indramayu merupakan salah satu kabupaten yang memiliki paling banyak sektor unggulan di wilayah ini. Beberapa sektor yang memiliki keunggulan kompetitif antara lain adalah sektor pertanian, kehutanan dan perikanan; pengadaan listrik dan gas; pengadaan air, pengelolaan sampah, limbah dan daur ulang; konstruksi; perdagangan besar dan eceran, reparasi mobil dan sepeda motor; transportasi dan pergudangan; real estat; administrasi pemerintahan, pertahanan dan jasa sosial wajib; dan jasa pendidikan. Sektor industri pengolahan yang merupakan penyumbang terbesar pada PDRB Kabupaten Indramayu, tidak termasuk kedalam sektor unggulan yang terdapat di Kabupaten Indramayu. Dengan demikian, Kabupaten Indramayu masih dapat meningkatkan pendapatannya dengan mengoptimalkan sektor - sektor lain yang memiliki keunggulan kompetitif.

Di Kabupaten Cirebon, terdapat 5 sektor yang memiliki keunggulan kompetitif, diantaranya adalah sektor pengadaan listrik dan gas; konstruksi; jasa keuangan dan asuransi; jasa perusahaan; dan jasa pendidikan. Sektor - sektor tersebut memiliki daya saing yang lebih tinggi dibandingkan dengan sektor yang sama di tingkat provinsi. Namun, sektor - sektor tersebut belum dapat memberikan kontribusi yang maksimal pada PDRB Kabupaten Cirebon. Sektor yang memberikan kontribusi terbesar pada PDRB Kabupaten Cirebon adalah sektor industri pengolahan dan pertanian, kehutanan dan perikanan. namun sektor tersebut tidak memiliki keunggulan kompetitif dibandingkan dengan sektor yang sama di tingkat provinsi.

Di Kota Cirebon, hanya terdapat dua sektor yang memiliki keunggulan kompetitif yakni sektor perdagangan besar dan eceran, reparasi mobil dan sepeda motor; dan sektor administrasi pemerintahan, pertahanan dan jaminan sosial. Hal tersebut sesuai dengan struktur PDRB Kota Cirebon dimana sektor perdagangan besar dan eceran, reparasi mobil dan sepeda motor memberikan kontribusi terbesar pada PDRB Kota Cirebon. Hal tersebut menunjukkan bahwa sektor yang menjadi unggulan di Kota Cirebon sudah cukup dioptimalkan oleh pemerintah setempat.

Di Kabupaten Majalengka tidak banyak sektor yang memiliki keunggulan kompetitif. Beberapa sektor yang unggul antara lain adalah industri pengolahan; pengadaan listrik dan gas; pengadaan air, pengelolaan sampah, limbah dan daur ulang; konstruksi; dan perdagangan besar dan eceran, reparasi mobil dan sepeda motor. Sementara itu, sektor pertanian, kehutanan dan perikanan, yang memberikan kontribusi terbesar pada PDRB Kabupaten Majalengka tidak memiliki keunggulan kompetitif.

Di Kabupaten Kuningan terdapat cukup banyak sektor yang memiliki keunggulan kompetitif diantaranya adalah sektor pertambangan dan penggalian; industri pengolahan; pengadaan listrik dan gas; konstruksi; perdagangan besar dan eceran, reparasi mobil dan sepeda motor; dan sektor jasa jasa. Sementara itu, sektor pertanian, kehutanan dan perikanan yang memberikan kontribu si terbesar pada PDRB Kabupaten Kuningan tidak memiliki keunggulan kompetitif. Oleh karena itu, pemerintah Kabupaten Kuningan dapat meningkatkan sektor - sektor lain yang memiliki keunggulan kompetitif.

Hasil analisis untuk bauran industri di wilayah IV Priangan menunjukkan pola yang sama dengan wilayah lainnya. Terdapat beberapa sektor yang memiliki nilai positif antara lain: sektor pengadaan air, pengelolaan sampah, limbah dan daur ulang; konstruksi; transportasi dan pergudangan; penyediaan akomodasi dan makan minum; informasi dan komunikasi; jasa keuangan dan asuransi; jasa perusahaan; jasa pendidikan; jasa kesehatan dan kegiatan sosial; jasa lainnya. Hasil tersebut menunjukkan bahwa pertumbuhan ekonomi di wilayah IV Priangan terkonsentrasi pada sektor - 
sektor tersebut, dimana pertumbuhan sektoral di wilayah ini lebih cepat dibandingkan dengan pertumbuhan sektor yang sama di tingkat provinsi.

Wilayah IV Priangan merupakan wilayah dengan jumlah kabupaten dan kota paling banyak di Provinsi Jawa Barat. Hasil analisis keunggulan kompetitif sektoral di wilayah ini juga sangat bervariasi sesuai dengan kekhususan di wilayah ini. Kabupaten/kota yang memiliki keunggulan kompetitif pada sektor pertanian, kehutanan dan perikanan di wilayah ini hanya terdapat pada Kabupaten Bandung Barat. Sementara itu, hampir seluruh kabupaten/kota di wilayah ini memiliki keunggulan kompetitif pada sektor pertambangan dan penggalian. Sektor industri pengolahan menjadi sektor yang unggul di beberapa wilayah yakni di Kabupaten Bandung; Kabupaten Bandung Barat; Kabupaten Garut; Kabupaten Tasikmalaya; dan Kabupaten Ciamis. Untuk sektor jasa - jasa, beberapa kabupaten/kota yang memiliki banyak keunggulan pada sektor jasa - jasa antara lain adalah Kota Bandung; Kota Cimahi; Kabupaten Sumedang; Kabupaten Tasikmalaya; dan Kabupaten Ciamis.

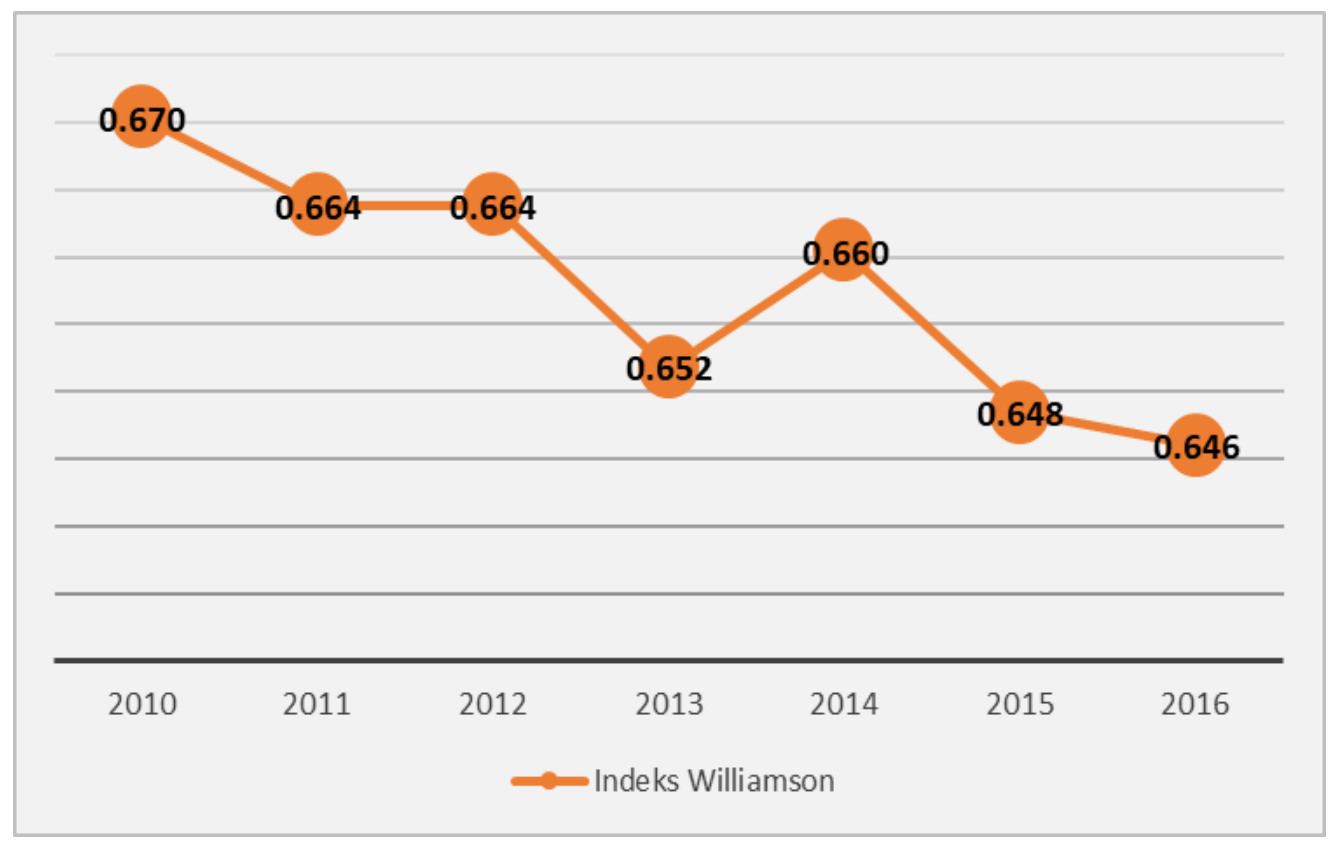

Sumber: BPS Provinsi Jawa Barat, 2017 (diolah)

Gambar 2.

Indeks Williamson di Provinsi Jawa Barat Tahun 2010 - 2016

Ketimpangan ekonomi di Provinsi Jawa Barat dapat dilihat dengan menggunakan Indeks William so n dan Indeks Theil. Analisis ketimpangan menunjukkan kondisi pembangunan ekonomi di suatu wilayah. Wilayah dengan ketimpangan yang tinggi menunjukkan distribusi pendapatan yang tidak merata dan dapat berdampak buruk terhadap pertumbuhan ekonomi suatu wilayah dalam jangka panjang. Gambar 2. menunjukkan angka ketimpangan PDRB perkapita antar daerah di Provinsi J awa Barat yang ditunjukkan dengan Indeks Williamson. Angka Indeks Williamson yang semakin kecil menunjukkan ketimpangan yang semakin kecil atau distribusi pendapatan yang semakin merata, dan sebaliknya apabila angka Indeks Williamson semakin besar atau mendekati satu menunjukkan terjadinya ketimpangan yang semakin besar. Pada periode tahun 2010 - 2016, tingkat ketimpangan di Provinsi Jawa Barat terus mengalami penurunan. Tingkat ketimpangan tertinggi terjadi pada tahun 2010 yang ditunjukkan dengan angka indeks Willliamson sebesar 0,67. Angka ini terus menurun 
hingga mencapai angka ketimpangan sebesar 0,646 pada tahun 2016 atau terkecil dalam kurun waktu tujuh tahun terakhir. Hal ini menunjukkan semakin kecilnya ketimpangan pendapatan di Provinsi Jawa Barat atau dengan kata lain, distribusi pendapatan di Provinsi Jawa Barat semakin merata pada beberapa tahun terakhir ini.

Meskipun secara umum, ketimpangan ekonomi di Provinsi Jawa Barat mengalami penurunan, namun kondisi yang berbeda dapat dialami oleh kabupaten/kota yang berada di Provinsi J awa Barat. Analisis ketimpangan per wilayah akan ditunjukkan dengan Indeks Theil yang menggaambarkan ketimpangan pendapatan di setiap kabupaten/kota pada kurun waktu tahun 2011 - 2016. Sama halnya dengan Indeks Willamson, semakin kecil angka indeks Theil menunjukkan semakin kecil ketimpangan yang terjadi, dan sebaliknya semakin besar angka indeks Theil maka semakin besar ketimpangan yang terjadi. Indeks theil wilayah I Bogor, tahun 2011 - 2016 menunjukkan ketimpangan di wilayah I Bogor berdasarkan angka indeks Theil, pada tahun 2011 - 2016. Secara umum, rata - rata pendapatan terbesar di wilayah I Bogor terdapat di Kabupaten Bogor, namun tingkat ketimpangan ekonomi paling kecil justru terdapat di Kabupaten Cianjur. Sementara itu, Kota Sukabumi merupakan kota dengan pendapat terkecil di wilayah ini, namun memiliki ketimpangan ekonomi yang paling besar di wilayah ini.

Secara umum, ketimpangan ekonomi di wilayah II Purwakarta terbilang cukup besar. Hampir seluruh kabupaten/kota yang terdapat di wilayah ini memiliki angka indeks Theil yang cukup tinggi. Hanya Kabupaten Subang yang memiliki angka indeks Theil paling rendah (dibawah 1). Hal ini sekaligus menunjukkan bahwa Kabupaten Subang merupakan kabupaten dengan tingkat ketimpangan paling kecil di wilayah II Purwakarta.

Dari sisi pendapatan daerah, pendapatan terbesar di wilayah II Purwakarta terdapat di Kabupaten Bekasi, diikuti dengan Kabupaten Karawang sebagai kabupaten kedua dengan pendapatan terbesar. Namun, di kedua wilayah tersebut, justru terdapat angka ketimpangan yang cukup besar. Sebaliknya, Kabupaten Subang dengan pendapatan paling kecil di wilayah II memiliki tingkat ketimpangan paling kecil di wilayah ini.

Pada wilayah III Cirebon, tingkat ketimpangan pendapatan cukup bervariasi (lihat Tabel 15). Tidak terdapat perbedaan yang cukup signifikan pada PDRB antar kabupaten/kota, namun tingkat ketimpangan di wilayah ini cukup beragam. Tingkat ketimpangan terbesar terdapat pada Kota Cirebon dengan angka Indeks Theil yang lebih dari 4. Sementara itu, tingkat ketimpangan terkecil terdapat di Kabupaten Cirebon.

Dari sisi pendapatan, Kabupaten Indramayu merupakan kabupaten dengan pendapatan terbesar di wilyah III Cirebon. Namun demikian, tingkat ketimpangan di kabupaten Indramayu juga terbilang cukup besar. Sementara itu, Kabupaten Kuningan, yang memiliki pendapatan paling rendah justru memiliki tingkat ketimpangan yang cukup kecil.

Pada wilayah IV Priangan, tingkat ketimpangan pendapatan di tiap kabupaten/kota sangat beragam. Ketimpangan pendapatan terbesar terdapat pada Kota Bandung, meskipun Kota Bandung merupakan kota dengan pendapatan terbesar di wilayah IV Priangan. Selanjutnya, Kota Cimahi juga memiliki ketimpangan yang cukup besar meskipun pendapat daerahnya tidak sebesar Kota Bandung.

Rata - rata tingkat ketimpangan yang paling kecil di wilayah IV Priangan terdapat pada Kabupaten Garut dan Tasikmalaya. Namun secara umum, dari tahun 2011 hingga 2016 tingkat ketimpangan pendapatan dapat dikatakan semakin menurun. 


\section{SIMPULAN DAN SARAN}

Secara umum, hasil analisis LQ menunjukkan terdapat beberapa daerah yang memiliki basis ekonomi pada sektor industri, antara lain: Kab. Bogor, Kab. Purwakarta, Kab. Karawang, Kab. Bekasi, Kab. Indramayu, Kab. Bandung, Kota Cimahi, dengan Wilayah II Purwakarta sebagai wilayah penyumbang terbesar untuk sektor industri. Beberapa daerah yang memiliki basis ekonomi pada sektor pertanian antara lain: Kab. Cianjur, Kab. Cirebon, Kab. Indramayu, Kab. Majalengka, Kab. Kuningan, Kab. Bandung Barat, Kab. Sumedang, Kab. Garut, Kab. Tasikmalaya, Kab. Ciamis, dan Kota Banjar. Secara umum, wilayah yang memberikan kontribusi terbesar untuk sektor pertanian adalah wilayah III Cirebon. Selanjutnya, beberapa daerah yang memiliki basis ekonomi pada sektor jasa - jasa antara lain adalah: Kota Bogor, Kota Sukabumi, Kab. Cianjur, Kab. Cirebon, Kota Cirebon, Kab. Kuningan, Kab. Bandung, dan Kota Bandung, dengan wilayah I Bogor merupakan wilayah yang berkontribusi terbesar untuk sektor jasa - jasa.

Tingkat ketimpangan pendapatan di Provinsi Jawa Barat mengalami penurunan dari 0,670 pada tahun 2010 menjadi 0,646 pada tahun 2016. Hal tersebut menunjukkan distribusi pendapatan yang semakin merata dalam kurun waktu tahun 2010 - 2016 di Provinsi Jawa Barat. Wilayah dengan rata - rata tingkat ketimpangan paling besar adalah Wilayah II Purwakarta dimana terdapat beberapa wilayah yang memiliki ketimpangan yang cukup besar seperti Kab, Purwakarta, Kab. Karawang, dan Kab. Bekasi. Sementara itu, wilayah dengan rata - rata tingkat ketimpangan paling kecil adalah Wilayah I Bogor dengan tingkat ketimpangan terkecil berada Kab. Cianjur.

\section{REFERENSI}

Amir, H., \& Nazara, S. (2005). Analisis Perubahan Struktur Ekonomi (Economic Landscape) dan Kebijakan Stra tegi Pembangunan Jawa Timur Tahun 1994 dan 2000: Analisis Input-Output. Jurnal Ekonomi dan Pembangunan Indonesia.https://doi.org/10.21002/jepi.v5i2.122

Ayu, D. F., Riani, W., \& Haviz, M.(2019). Pengaruh PertumbuhanEkonomi , Pen ga nggu ran , da n Jumlah Penduduk terhadap Ketimpangan Pendapatan di Provinsi Ja wa Barat Tahun 2005-2016. Prosiding Ilmu Ekonomi, 5(1), 214-220.

Badan Pusat Statistik. (2016). Provinsi Jawa Barat Dalam Angka 2016, 683. Retrieved from https://jabar.bps.go.id/publication/2016/07/15/2297a52073f5f32eca26eb8a/provinsi-ja wa-barat-dalama ngka-2016.html

Basuki, A., \& Gayatri, U. (2009). Penentu Sektor Unggulan Dalam Pembangunan Daerah: Studi Kasus di Kabupaten Ogan Komering Ilir. Jurnal Ekonomi \& Studi Pembangunan. https://doi.org/10.18196/jesp.10.1.1280

BPS. (2019). Provinsi Jawa Barat Dalam Angka 2018. BPS Provinsi Jawa Barat.

BPS Provinsi Ja wa Barat. (2017). Provinsi Jawa Barat DalamAngka2017 (1 st ed., Vol. 1). B a ndung: B PS Provinsi Jawa Barat. Retrieved from https://jabar.bps.go.id/publication/2017/08/12/62379e17bcc20052a7991d35/provinsi-jawa-ba rat-da lamangka-2017.html

Chenery, H., \& Srinivasan, T. N. (1988). Handbook of development economics. Volume 1. Handbook of Development Economics. Volume 1.https://doi.org/10.2307/2233580

Hidayat, J. A. . (2013). Ana lisis Struktur Perekonomian Di Kota Manado. Jurnal Emba.

Hill, H. (2000). The Indonesian Economy. The Indonesian Economy. https://doi.org/10.1017/cbo9780511818189

KARIYASA, K. (2006). Perubahan StrukturEkonomi dan Kesempatan Kerja Serta Kualitas Su mberdaya Manusia di Indonesia. SOCA: Socioeconomics of Agriculture and Agribusiness.

Loveridge, S. (1995). A Pra ctical Approach to Shift-Share Analysis. Community Development Society. Journal, 26(1). https://doi.org/10.1080/15575339509490166

Ma'mun, D., \& Irwansyah, S. (2014). Ana lisis Pergeseran Struktur Ekonomi dan Identifikasi Sek tor Potensial Wilayah Pengembangan (Studi Ka sus di Kabupaten Bekasi, Provinsi Ja wa Barat). Jurnal Social Economic of Agriculture, 2(1).https://doi.org/10.26418/j.sea.v2i1.5116

Mura, L., Ha vierniková, K., \& Ma chová, R. (2017). Empirical results of entrepreneurs' network: Case study of 
Slovakia. Serbian Journal of Management, 12(1). https://doi.org/10.5937/sjm12-10418

Pemprov Jawa Barat. (2020). Ja barprov.go.id.

Putra, P.I.P., \& Yadnya,I.P. (2018). Analisis Sektor Unggulan Perekonomian di Kabupaten/Kota Den pasar, Badung, Gianyar, dan Tabanan. E-Jurnal Manajemen Universitas Udayana. https://doi.org/10.24843/ejmunud.2018.v07.i10.p 16

Ratnasari, L. (2017). Pengaruh pertumbuhan ekonomiterhadap ketimpangan distribusi pendapatan di Indonesia . E-Jurnal PerspektifEkonomi Dan Pemban gunan Daerah.

Reza, M., Ja mal, A., \& Zulham, T. (2019). Analisis Ketimpangan Pembangunan dan Distribu si Pend apatan Wilayah di Provinsi Aceh. Jurnal Ekonomi Dan Kebijakan Publik Indonesia, 6(1). https://doi.org/10.24815/ekapi.v6i1.14256

Taniu, S., Yakup, A. P., \& Novria nsyah, M. A. (2020). Shift Share Analysis to Determine Sectoral Performan ce of the Sectoral Economy of the Gorontalo Regional. Gorontalo Development Review, 3(2). https://doi.org/10.32662/golder.v3i2.1088

Todaro, M., \& Smith, S. C. (2011). Economic Development (1 1 th ed.). Economic Development. 